\title{
A weak health response is increasing the risk of excess mortality as food crisis worsens in Somalia
}

\author{
Andrew Seal ${ }^{* *}$, Francesco Checchi ${ }^{2}$, Nancy Balfour ${ }^{3}$, Abdi-Rashid Haji Nur ${ }^{4}$ and Mohamed Jelle
}

Since 1991, Somalia has been afflicted by conflict involving factions within the country, regional powers, and international actors. Following a year of failed rains the current humanitarian situation in Somalia is extremely serious. Early warning alerts have been issued and the UN has launched an appeal aiming to prevent the onset of famine and its defining features of extreme food insecurity, malnutrition, and excess mortality [1]. Large scale distress migration has been reported with 599,000 people moving due to the crisis since November 2016, including 59,000 in the first 2 weeks of April [2].

While the focus of the response is understandably on food assistance (including cash transfers) the health situation is equally alarming. Infectious diseases are major causes of excess mortality under the famine-like conditions that are expected over the next few months [3].

Chronic insecurity has contributed to a degraded health system and humanitarian actors have become important providers of health services. Following the withdrawal of MSF in 2013 and problems in implementing alternative programmes, the health system within Somalia, particularly southern Somalia, has severe capacity constraints [4].

Water availability in southern Somalia is critical following the drying of the Shabelle River in January. While the $\mathrm{Gu}$ rainy season has now started, extensive damage to crops, pasture and livelihoods has already occurred and the adequacy and extent of rainfall remains uncertain [5]. An outbreak of cholera is spreading rapidly with 28,408 cases and 558 deaths reported this year up to April 16th and this is likely to accelerate with the onset of the $\mathrm{Gu}$ rains
[6]. An oral cholera vaccination campaign was announced by WHO and the MOH on March 15th. However, the speed at which this can be implemented may not contain the outbreak. Problems of capacity, funding, and access are limiting the scale up of standard and effective responses, including water, sanitation, and hygiene activities to control the spread of cholera.

Measles vaccination coverage within Somalia is generally poor. A large outbreak of measles took place in Kismayo at the end of 2016 and newly available verbal autopsy data indicate that measles has caused 9\% of deaths in displaced children in Mogadishu during this pre-famine stage [7]. Measles is an important cause of death in famine and any residual herd immunity from the widespread outbreaks in 2011 will have waned by now due to the build-up of a susceptible pool of unvaccinated children under $5 \mathrm{y}$ - i.e. the likely famine event may unfortunately coincide with the normal cycle of measles outbreaks in such settings. While Somalia lacks a centralised measles surveillance system, the latest media report indicate 5700 suspected cases since the start of the year [8]. A vaccination campaign was belatedly announced in Baidoa on April 25th but is designed to have limited geographical coverage, excluding many areas where internally displaced people are known to be concentrating [9].

As of April 3rd, the Somalia Health Cluster reported that only $7 \% \%$ of the \$US 85 million requested for health interventions had been provided [10]. Somalia is an extremely difficult operating environment but WHO needs to rapidly enhance its humanitarian health coordination role and partners need to effectively scale up public health interventions, particularly vaccination.

* Correspondence: a.seal@ucl.ac.uk

${ }^{1}$ Institute for Global Health, UCL, London, UK

Full list of author information is available at the end of the article 


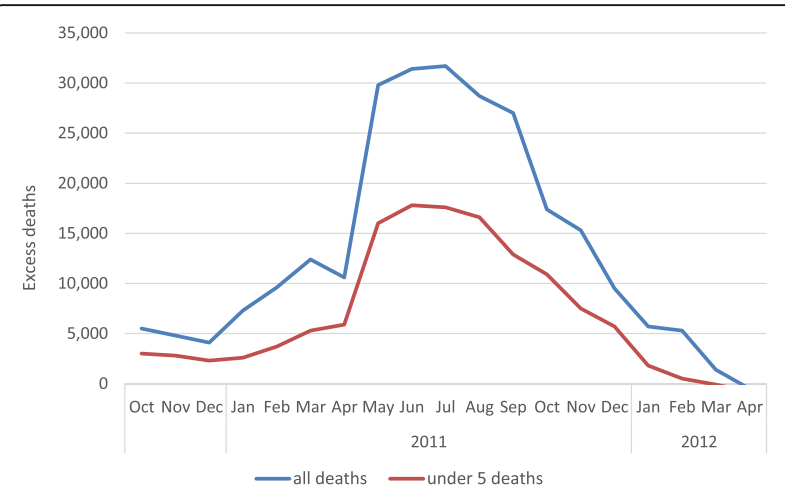

Fig. 1 Estimated excess mortality by month during the 2011 famine in Somalia

Famine occurred in southern Somalia in 2011 and caused the deaths of an estimated 258,000 people (Fig. 1) [11]. 2017 could be worse and a more effective health response is urgently needed.

\section{Acknowledgements}

None.

\section{Funding}

No funding source or payment for the writing of this manuscript or in the decision to submit it for publication.

The corresponding author had full access to all the data in the study and had final responsibility for the decision to submit for publication.

\section{Availability of data and materials}

Not applicable.

\section{Authors' contributions}

AS: drafted the article. All authors contributed to revisions of the manuscript and read and approved the final version.

\section{Competing interests}

Andrew Seal; Francesco Checchi; Nancy Balfour; Abdi-Rashid Haji Nur; Mohamed Jelle; has nothing to disclose.

\section{Consent for publication}

Not applicable.

\section{Ethics approval and consent to participate}

Not applicable.

\section{Publisher's note}

Springer Nature remains neutral with regard to jurisdictional claims in published maps and institutional affiliations.

\section{Author details}

${ }^{1}$ Institute for Global Health, UCL, London, UK. ${ }^{2}$ Epidemiology and International Health, London School of Hygiene and Tropical Medicine, London, UK. ${ }^{3}$ Centre for Humanitarian Change, Nairobi, Kenya. ${ }^{4}$ Concern Worldwide, Mogadishu, Somalia.

Received: 2 May 2017 Accepted: 30 May 2017

Published online: 03 July 2017

\section{References}

1. Somalia Operational Plan for Famine Prevention (Jan - Jun 2017). OCHA on Behalf of the Humanitarian Country team (HCT), February 2017. Available from: https://www.humanitarianresponse.info/en/operations/somalia/ document/somalia-operational-plan-famine-prevention-17-february-2017.
2. Drought displacements in period 1 Nov 2016 to 14 April 2017. UNHCR/NRC, April 23rd 2017. Available from: http://data.unhcr.org/horn-of-africa/country. php?id=197.

3. Salama P, Assefa F, Talley L, Spiegel P. Van d, V, Gotway CA. Malnutrition, measles, mortality, and the humanitarian response during a famine in Ethiopia. JAMA. 2001;286(5):563-71.

4. Burki TK. Somalia: a gathering storm? Lancet. 2013;382(9900):1237-8. doi:10. 1016/50140-6736(13)62083-8.

5. Somalia Drought Watch. FAO/SWALIM/FSNAU, April 6th, 2017. Available from: http://www.faoswalim.org/water-resources.

6. EMRO. Cholera outbreak: World Health Organisation 2017 [26/04/2017]. Available from: http://www.emro.who.int/health-topics/cholera-outbreak/ index.html.

7. Jelle M, Fottrell E, Grijalva-Eternod C, Cox C, Seal A. Ascertainment of the causes of child death in Somalia IDP by verbal autopsy. 2017.

8. Wesangula D. Measles surges among children in famine-threatened Somalia. Reuters. 2017

9. In drought-hit Somalia, children also face potentially deadly measles threat: UNICEF Somalia; 2017 [updated April 25th, 2017; cited 2017 April 27th]. Available from: https://www.unicef.org/somalia/media_19855.html.

10. Monthly Bulletin, 15th March to 3rd April 2017. Health Cluster Somalia, 2017. Available from: https://www.humanitarianresponse.info/system/files/ documents/files/health_cluster_bulletin_march_2017.pdf.

11. Checchi F, Robinson W. Mortality among populations of southern and central Somalia affected by severe food insecurity and famine during 20102012. FAO \& FEWS-NET, 2013 February 5th. Available from: http://www. fsnau.org/downloads/Somalia_Mortality_Estimates_Final_Report_8May2013_ upload.pdf.
Submit your next manuscript to BioMed Central and we will help you at every step:

- We accept pre-submission inquiries

- Our selector tool helps you to find the most relevant journal

- We provide round the clock customer support

- Convenient online submission

- Thorough peer review

- Inclusion in PubMed and all major indexing services

- Maximum visibility for your research

Submit your manuscript at www.biomedcentral.com/submit
C Biomed Central 